\title{
Activation of the prostaglandin FP receptor in human granulosa cells
}

\author{
M. P. Carrasco, G. Asbóth, S. Phaneuf and A. López Bernal* \\ Nuffield Department of Obstetrics and Gynaecology, University of Oxford, John Radcliffe Hospital, \\ Oxford OX3 9DU, UK
}

\begin{abstract}
Prostaglandin $\mathrm{F}_{2 \alpha}\left(\mathrm{PGF}_{2 u}\right)$ has regulatory (mainly luteolytic) effects in the ovary but the mechanism of action is not completely understood. Reverse transcriptase-polymerase chain reaction (RT-PCR) techniques were used to demonstrate the presence of mRNA encoding the $\mathrm{PGF}_{2 \alpha}$ receptor (FP receptor) in human granulosa-lutein cells. Specific primers for the amplification of cDNA were designed and yielded a single product of $696 \mathrm{bp}$ corresponding to the FP receptor. The identity of this product was verified by sequencing. Fluprostenol, a selective FP receptor agonist, activated phospholipase $C$ (PLC) and increased intracellular free calcium concentration, confirming the functional activation of the receptor. We have demonstrated by Western blotting that granulosa cells express PLC- $\beta$ and PLC- $\gamma$ isoforms. The cells responded to pervanadate with increased PLC activity and increased tyrosine phosphorylation, demonstrating a functional PLC- $\gamma$ tyrosine kinase pathway. However, fluprostenol did not provoke any detectable tyrosine phosphorylation. Moreover, the effect of fluprostenol was inhibited through protein kinase $C$ stimulation by phorbol 12,13dibutyrate, and was not affected when cells were treated with phenylarsine oxide, which blocks tyrosine phosphorylation. These results suggest that the FP receptor activates PLC- $\beta$ rather than PLC- $\gamma$ isoforms. Fluprostenol-induced activation was pertussis toxin resistant. Granulosa cells express $G$ proteins of the $G_{q}$ family (resistant to pertussis toxin) and mRNA for both $\mathrm{G} \alpha_{q}$ and $\mathrm{G} \alpha_{11}$ has been identified by RT-PCR. In conclusion, human granulosa cells have a functional FP receptor the effects of which are mediated through PLC- $\beta$ activation probably via $G_{q / 11}$.
\end{abstract}

\section{Introduction}

Prostaglandins (PGs) are involved in the regulation of granulosa and luteal cell function but their mechanism of action is not completely understood. $\mathrm{PGE}_{2}$ has luteotrophic effects both in vivo and in vitro (McNatty et al., 1975) and stimulates progesterone output by human granulosa cells obtained from follicles at different stages of development (McNatty et al., 1975). The effect of $\mathrm{PGE}_{2}$ is associated with an increase in cyclic adenosine- $3^{\prime}, 5^{\prime}$-monophosphate (cAMP) and is mediated by prostaglandin $\mathrm{EP}_{2}$ receptors coupled to adenylyl cyclase (Dennefors et al., 1982; Michael et al., 1993; López Bernal et al., 1995). By contrast, the action of $\mathrm{PGF}_{2 \alpha}$ appears to be more complex. In cultured human granulosa cells $\mathrm{PGF}_{2 u}$ inhibits progesterone output and antagonises the stimulatory effect of hCG (McNatty et al., 1975; Michael and Webley, 1991); a similar luteolytic effect has been described in several primate and non-primate species (Thomas et al., 1978; Hamberger et al., 1979; Pate and Condon, 1984). The antigonadotrophic action of $\mathrm{PGF}_{2 \alpha}$ may involve inhibitory effects at sites both before and after adenylyl cyclase activation, probably mediated by protein kinase C (PKC) activation (Michael and Webley, 1993) but it could also result from potentiation of the inhibitory effects of

${ }^{*}$ Correspondence.

Received 12 June 1997. other luteolytic agents, for example endothelin-I (Prins et al., 1994; Liebermann et al., 1996). The presence of $\mathrm{PGF}_{2 a}$ receptors (FP receptors) in human and non-primate granulosa-luteal cells has been demonstrated by binding studies (Powell et al., 1974) and the FP receptor has been cloned from ovarian complementary DNA (cDNA) libraries in mice, rats and sheep (Lake et al., 1994; Kitanaka et al., 1994; Sakamoto et al., 1994; Sugimoto et al., 1994; Graves et al., 1995). Ristimäki et al. (1997) have cloned a partial cDNA sequence of the FP receptor in human granulosa cells. The expression of mRNA encoding FP receptor was increased by hCG administration in vitro (Ristimäki et al., 1997).

FP receptors belong to the $G$ protein-coupled receptor superfamily and they are thought to operate through activation of the inositol phospholipid pathway (Houmard et al., 1992). The hydrolysis of phosphatidylinositol 4,5-bisphosphate by a phospholipase C (PLC) generates two molecules with second messenger function: inositol 1,4,5-trisphosphate which mobilizes calcium from the sarcoplasmic reticulum and 1,2diacylglycerol which activates PKC. Houmard et al. (1992) reported that $\mathrm{PGF}_{2 \alpha}$ is a potent activator of PLC in a primate (rhesus monkeys) corpus luteum. Moreover, $\mathrm{PGF}_{2 a}$ increases intracellular free calcium $\left(\left[\mathrm{Ca}^{2+}\right]_{i}\right)$ in human granulosa cells (Currie et al., 1992). However, uncertainty remains as to whether PLC activation and changes in $\left[\mathrm{Ca}^{2+}\right]_{\mathrm{i}}$ are required for $\mathrm{PGF}_{2 u}$ to exert its luteolytic effect. For example, in marmoset 
monkeys in the late luteal phase $\mathrm{PGF}_{2 \alpha}$ has a strong luteolytic and antigonadotrophic effect which apparently occurs without PLC activation (Michael and Webley, 1993). Moreover, phosphatidylinositol hydrolysis can be catalysed not only by $G$ protein-dependent PLC isoenzymes (PLC- $\beta$ family), but also by a variety of receptor-tyrosine kinase-dependent enzymes (PLC- $\gamma$ family). It has been reported that PGF $_{2 \alpha}$ rapidly increases tyrosine phosphorylation in some cell lines (Watanabe et al., 1994) but is not known whether this happens in granulosa cells.

The purpose of this paper was to investigate the second messenger pathway for FP receptors in cultured human granulosa cells. Fluprostenol, a synthetic $\mathrm{PGF}_{2 \alpha}$ analogue, which is a selective FP receptor agonist (Dukes et al., 1974; Carrasco et al., 1996) was used and its effects on PLC- $\beta$ and PLC- $\gamma$ activation were studied. The presence of mRNA encoding the FP receptor was confirmed and mRNAs encoding two distinct $G$ proteins, $\mathrm{G} \alpha_{\mathrm{q}}$ and $\mathrm{G} \alpha_{11}$, which are known to activate PLC- $\beta$, were demonstrated.

\section{Materials and Methods}

\section{Materials}

Materials used in this study were purchased from the following sources: $\left[{ }^{3} \mathrm{H}\right]$ myo-inositol (1.5 TBq mmol-1), horseradish-peroxidase-conjugated sheep anti-mouse $\operatorname{IgG}$, horseradish-peroxidase-conjugated goat anti-rabbit $\operatorname{IgG}$ and enhanced chemiluminescense detection kits (ECL) were obtained from Amersham International plc (Amersham). Oxytocin was from Calbiochem-Novabiochem (Nottingham). $\mathrm{PGF}_{2 \alpha^{\prime}}$ sodium orthovanadate, phorbol 12,13-dibutyrate $(\mathrm{PDBu})$, phenylarsine oxide (PAO), pertussis toxin, thapsigargin and fatty acid-free bovine serum albumin (BSA) were from Sigma Chemical Co. Ltd (Poole). Anti-phospholipase $C$ antibodies G12 (PLC- $\beta 1$ ), Q-15 (PLC- $\beta 2$ ), C-20 (PLC- $\beta 3$ ), C-18 (PLC- $\beta 4$ ), 1249 (PLC- $\gamma 1$ ) and C-19 (PLC- $\gamma 2$ ) and their respective cognate peptides were from Santa Cruz Biotechnology Inc. (Santa Cruz, CA). Anti-phosphotyrosine mouse monoclonal antibody 4G-10 was purchased from Upstate Biotechnology Incorporated (Lake Placid, NY). Fura-2-acetoxymethyl ester and Pluronic F-127 were obtained from Molecular Probes (Eugene, OR). Tissue culture reagents were from Life Technologies (Paisley). All other reagents were commercial preparations of the highest available purity. Fluprostenol was kindly supplied by R. Coleman (formerly at Glaxo, UK).

\section{Preparation and incubation of human granulosa cells}

Granulosa cells were collected with consent of the patients and approval by the Central Oxfordshire Ethics Committee from women undergoing routine oocyte retrieval for in vitro fertilization. Follicular growth was stimulated by daily injection of gonadotrophins in patients previously desensitized with a long course of GnRH (López Bernal et al., 1995). Follicles were aspirated $35 \mathrm{~h}$ after administration of 10000 iu of hCG (Profasi, Serono Labs UK, Ltd, Hertfordshire). After removal of any oocytes present, follicular fluids were centrifuged at $340 \mathrm{~g}$ at room temperature for $10 \mathrm{~min}$ through Ficoll-Paque
(Pharmacia, St Albans) to remove blood cells. Granulosa cell layers were subsequently dispersed with collagenase (Sigma Co. Ltd, Poole; diluted to $300 \mathrm{U} \mathrm{ml}^{-1}$ ) and Trasylol (Bayer UK, Newbury; diluted to $100 \mathrm{U} \mathrm{ml}^{-1}$ ) for $20 \mathrm{~min}$ at $37^{\circ} \mathrm{C}$ in I mmol CaCl${ }_{2} \mathrm{I}^{-1}$. Viability of cells after dispersion was $80 \%$ as detected by Trypan blue staining and the yield per patient was $0.4-1.5 \times 10^{6}$ cells.

Cells were seeded at $40 \times 10^{3}$ cells $\mathrm{cm}^{-2}$ in fibronectincoated flasks and cultured in Ham's F12:DEM (1:I by volume) medium containing $10 \%(\mathrm{v} / \mathrm{v})$ fetal calf serum, $10 \%(\mathrm{v} / \mathrm{v})$ horse serum, $1 \mathrm{mmol}$ vitamin $\mathrm{El}^{-1}, 20 \mathrm{nmol}$ selenium $\mathrm{l}^{-1}$ and $100 \mathrm{U}$ penicillin/streptomycin $\mathrm{ml}^{-1}$. Under these conditions the cells retained $3 \beta$-hydroxysteroid dehydrogenase and aromatase activities and remained responsive to hCG by increasing progesterone output (López Bernal et al., 1995). The cells were used within the first week in culture.

\section{${ }^{3}$ H]inositol labelling}

Labelling of phosphoinositides was performed by incubating granulosa cells with $0.25 \mathrm{MBq}\left[{ }^{3} \mathrm{H}\right]$ myo-inositol $\mathrm{ml}^{-1}$ in Waymouth culture medium complemented with penicillin, streptomycin and $2 \%$ (v/v) FCS for $48 \mathrm{~h}$ (Carrasco et al., 1996). The cells were stimulated with fluprostenol for $30 \mathrm{~min}$ or pervanadate for $15 \mathrm{~min}$ in a Hank's balanced salt solution (HBSS) buffer containing $1 \mathrm{mg}$ fatty acid-free BSA $\mathrm{ml}^{-1}$ and $12 \mathrm{mmol} \mathrm{LiCl} l^{-1}$ in a final volume of $250 \mu \mathrm{l}$. The reaction was stopped with chloroform:methanol:hydrochloric acid (50:100:1, $\mathrm{v}: \mathrm{v}: \mathrm{v})$. Inositol phosphates (IPs) in the water-soluble phase were separated and quantified according to the method of Bone $e t$ al. (1984) using Dowex resin columns. Aliquots of the lipid phase were counted for the determination of the labelling of the phospholipids.

\section{Measurements of free $\left[\mathrm{Ca}^{2+}\right]_{i}$}

Measurements of $\left[\mathrm{Ca}^{2+}\right]_{\mathrm{i}}$ were carried out in granulosa cells grown on coverslips. The coverslips were loaded with $5 \mu \mathrm{mol}$ Fura- 2 acetoxymethylester $1^{-1}$ in HBSS in the presence of $0.1 \%$ $(\mathrm{w} / \mathrm{v})$ Pluronic F-127 detergent for $30 \mathrm{~min}$ at $37^{\circ} \mathrm{C}$ in the dark. The cells were washed with HBSS and stored at room temperature until fluorometry. Fluorometric measurements were made by the method of Grynkiewicz et al. (1985) in a Shimadzu RF 5001 spectrofluorimeter (Howe, Bicester) controlled by a Viglen 386 SX PC, equipped with a dualwavelength determination software (Shimadzu), as described by Asbóth et al. (1996). Free intracellular calcium was calculated from the ratio of fluorescence emitted at $510 \mathrm{~nm}$ using excitation wavelength of 350 and $380 \mathrm{~nm}$. The depletion of intracellular $\mathrm{Ca}^{2+}$ storages was undertaken by 10 min pretreatment with $100 \mathrm{nmol}$ thapsigargin $1^{-1}$. Experiments under low extracellular $\mathrm{Ca}^{2+}$ conditions were carried out in HBSS without $\mathrm{Ca}^{2+}$ and $\mathrm{Mg}^{2+}$ in the presence of $100 \mu \mathrm{mol}$ ethyleneglycol-bis( $\beta$-aminoethyl ether)- $N, N, N^{\prime}, N^{\prime}$-tetraacetic acid $\mathrm{I}^{-1}$ (Carrasco et al., 1996).

\section{Immunodetection of phospholipase $C$}

PLC isoforms were detected by western blotting in membrane and cytosol fractions of granulosa cells essentially as 
described by Phaneuf et al. (1996). Proteins were separated by SDS-PAGE $(7.5 \%$ acrylamide) for $45 \mathrm{~min}$ at $200 \mathrm{~V}$, and transferred to nitrocellulose using a Bio-Rad semi-dry electroblot-

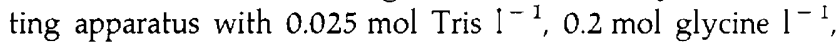
$20 \%$ methanol, $\mathrm{pH} 8.6$ at $13 \mathrm{~V}$ for $2 \mathrm{~h}$. After transfer, the nitrocellulose papers were incubated in PBS-Tween (phosphate-buffered saline, Tween-20 0.1\%, v/v), containing $2 \%$ skimmed milk overnight at room temperature. Nitrocellulose papers were then incubated with anti-phospholipase $C$ antibodies at a 1:1000 dilution for $1 \mathrm{~h}$ at $4^{\circ} \mathrm{C}$ in PBS-Tween containing $0.15 \%$ skimmed milk. The blots were washed three times in PBS-Tween, and then incubated with goat anti-rabbit immunoglobulin $G$ coupled to horseradish peroxidase at a $\mathrm{I}: 1000$ dilution for $\mathrm{Ih}$ at room temperature in PBS-Tween. Finally the blots were washed three times in PBS. Chemiluminescense detection (ECL) was carried out according to the technical notes provided by Amersham, with Kodak X-Omat XAR film.

\section{Tyrosine phosphorylation assay}

Treatments with fluprostenol, pervanadate or oxytocin were carried out on granulosa cells grown on $25 \mathrm{~cm}^{2}$ plastic culture flasks as described by Carrasco et al. (1996). Briefly, cells were washed with HBSS, then incubated with $1 \mu \mathrm{mol}$ fluprostenol or oxytocin $1^{-1}$ for $30 \mathrm{~min}$ at $37^{\circ} \mathrm{C}$, or with pervanadate ( $400 \mu \mathrm{mol}$ sodium orthovanadate $\mathrm{I}^{-1}, 2$ mmol $\mathrm{H}_{2} \mathrm{O}_{2} \mathrm{l}^{-1}$ ) for $15 \mathrm{~min}$ at $37^{\circ} \mathrm{C}$. The reactions were stopped by removing the medium and by washing with ice-cold HBSS. The cells were scraped from the flasks and pelleted by centrifugation at $1000 \mathrm{~g}$ for $15 \mathrm{~min}$ ? The pellets were solubilised in SDS buffer containing $8 \mathrm{~mol}$ urea $\mathrm{I}^{-1}$ and heated at $95^{\circ} \mathrm{C}$ for $10 \mathrm{~min}$ before electrophoresis.

After transfer, the nitrocellulose was saturated with $10 \%$ BSA in PBS-Tween for $30 \mathrm{~min}$ at $4^{\circ} \mathrm{C}$. Nitrocellulose papers were then incubated with anti-phosphotyrosine mouse monoclonal antibodies at 1:1000 overnight at $4^{\circ} \mathrm{C}$ in the same solution. The blots were washed three times in PBS-Tween, and then incubated with mouse antibodies coupled to horseradish peroxidase at $1: 10000$ for $\mathrm{Ih}$ at room temperature in PBS-Tween containing 1.5\% BSA. Finally the blots were washed three times in PBS-Tween. Antibody complexes were detected by ECL using Kodak X-Omat XAR film.

\section{RNA isolation}

Total cellular RNA was prepared using a modification of the guanidine isothiocyanate method (Chirgwin et al., 1979). Briefly, cells (approximately $10^{6}$ ) were solubilized with guanidium isothiocyanate and layered onto a $8 \mathrm{ml}$ cushion of caesium chloride and sedimented at $175000 \mathrm{~g}$ for $20 \mathrm{~h}$ at $20^{\circ} \mathrm{C}$, in a Beckmann SW 41Ti-rotor. RNA concentrations were determined by UV absorption at $260 \mathrm{~nm}$. The $28 / 18 \mathrm{~S}$ ribosomal RNA integrity was assessed in agarose gel electrophoresis.

\section{Reverse transcriptase-polymerase chain reaction (RT-PCR)}

Synthesis of cDNA was carried out with the ReverseTranscriptor kit (R\&D Systems Europe Ltd, Abingdon). Briefly,
$2 \mu \mathrm{g}$ of RNA were annealed to oligo $\mathrm{d}(\mathrm{T})$ primers. The cDNA was used immediately for PCR or stored at $-20^{\circ} \mathrm{C}$ until use.

The selection of the polymerase chain reaction (PCR) primers was performed using the Wisconsin Package (Genetics Computer Group). On the basis of the human sequence for FP receptor (Abramovitz et al., 1994), Ga $\alpha_{\mathrm{q}}$ protein (Chen et al., 1996) and $\mathrm{Ga}_{11}$ protein (Jiang et al., 1991) the following oligonucleotides were chosen:

Forward and reverse primers for FP receptor were 1006 $5^{\prime}$ GTCTCCTGTATTTGTTGGAGCC and 1701 5' GAG CGGTGATCTCAAAATAACC, respectively. These primers would amplify a 696 bp fragment.

Forward and reverse primers for $\mathrm{G} \alpha_{\mathrm{q}}$ were $3575^{\prime} \mathrm{GGA}$ CAGGAGAGAGTGGCAAG and $8645^{\prime}$ TTTCTTCTCTCT GACCTTTGGC, respectively. These primers would amplify a 508 bp fragment.

Forward and reverse primers for $\mathrm{G} \alpha_{11}$ were $3835^{\prime} \mathrm{GCT}$ ACTCGGAGGAGGACAAG and $9115^{\prime}$ GACTCCACCAGG ACTTGGTC, respectively. These primers would amplify a 529 bp fragment.

PCR was performed in a final volume of $10 \mu \mathrm{l}$ containing $100 \mathrm{ng}$ cDNA, $10 \mathrm{mmol}$ Tris- $\mathrm{HCl} \mathrm{l}^{-1}, \mathrm{pH} 8.3,50 \mathrm{mmol} \mathrm{KCl}$ $1^{-1}, 1.5 \mathrm{mmol} \mathrm{MgCl} 1^{-1}, 0.001 \%(\mathrm{w} / \mathrm{v})$ gelatin, $200 \mu \mathrm{mol}$ of each deoxynucleotide triphosphate (dNTP) $I^{-1}, 1 \mu \mathrm{mol}$ of each primer $l^{-1}$ and $0.25 \mathrm{U}$ AmpliTaq DNA polymerase. The PCR reaction was: $94^{\circ} \mathrm{C}$ for $5 \mathrm{~min}$, then 30 cycles of $94^{\circ} \mathrm{C}$ for $1 \mathrm{~min}$, $60^{\circ} \mathrm{C}$ (for $\mathrm{FP}$ receptor) or $62^{\circ} \mathrm{C}$ (for $\mathrm{G} \alpha_{q}$ protein) or $59^{\circ} \mathrm{C}$ (for $\mathrm{G} \alpha_{11}$ protein) for $1 \mathrm{~min}$ and $72^{\circ} \mathrm{C}$ for $2 \mathrm{~min}$, with a final elongation step of $72^{\circ} \mathrm{C}$ for $5 \mathrm{~min}$. The products generated were subjected to electrophoresis on $1.5 \%$ agarose gel containing ethidium bromide and visualized by UV irradiation. The identity of the fragments was verified by sequencing with thermo sequenase radiolabelled terminator cycle sequencing kit (Amersham International, Aylesbury).

\section{Statistical analysis}

Estimations were carried out with a minimum of four replicates and experiments were performed at least twice using granulosa cells obtained from different donors. Statistical comparisons were performed using Student's $t$ test. Differences were considered significant if $P<0.05$.

\section{Results}

\section{Expression of FP receptor gene in human granulosa cells}

The presence of FP receptor mRNA in human granulosa cells was demonstrated by RT-PCR analysis using FP receptorspecific primers that were designed to produce a $696 \mathrm{bp}$ fragment. This resulted in the amplification of a single band for the three patients tested (Fig. 1). The identity of the PCR product was confirmed by sequencing which showed $100 \%$ homology with the published sequence for the FP receptor (Abramovitz et al, 1994).

\section{Effects of fluprostenol on the formation of $\left.{ }^{3} H\right] I P_{S}$ and intracellular calcium concentration}

Fluprostenol induced a concentration-dependent increase in total $\left.{ }^{3} \mathrm{H}\right] \mathrm{IPs}$, with an $\mathrm{EC}_{50}$ value of $26 \mathrm{nmol}^{-1}$ and a maximal 


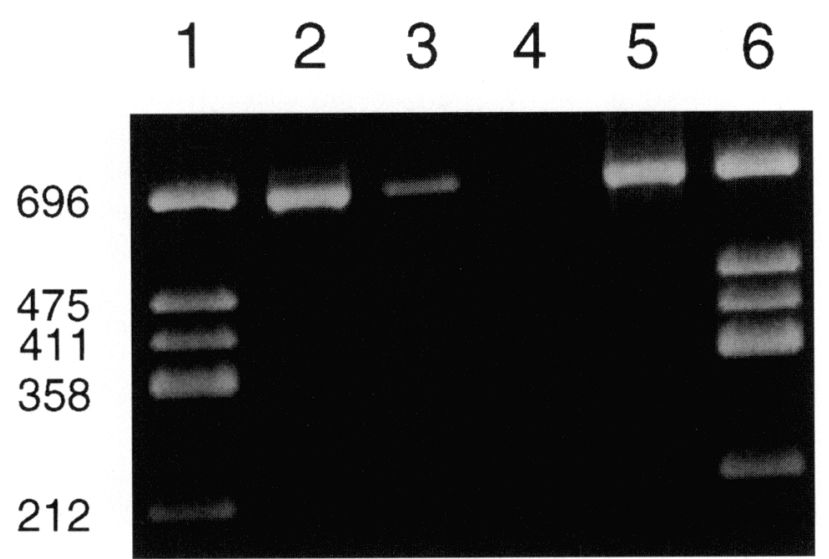

Fig. 1. Expression of FP receptor gene in human granulosa cells. RT-PCR analysis of FP receptor produced the expected $696 \mathrm{bp}$ band (lanes 2, 3 and 5; three different donors). A PCR sample without RNA transcribed product was loaded in lane 4 (blank). Lanes 1 and 6 contained DNA markers, the molecular size (bp) of which is given on the left. The identity of the PCR products was confirmed by sequencing.

response at $1 \mu \mathrm{mol} 1^{-1}$ (Fig. 2a). Moreover fluprostenol increased $\left[\mathrm{Ca}^{2+}\right]_{i}$ with an $\mathrm{EC}_{50}$ value of $12 \mathrm{nmol} \mathrm{l}^{-1}$ (Fig. 2b). These results demonstrate that human granulosa cells possess a functional FP receptor with high affinity for fluprostenol. This receptor stimulates $\mathrm{PLC}$ and increases $\left[\mathrm{Ca}^{2+}\right]_{i}$ probably by $\mathrm{Ca}^{2+}$ mobilization from the endoplasmic reticulum, as supported by the fact that depletion of intracellular $\mathrm{Ca}^{2+}$ stores with thapsigargin (Thastrup et al., 1990) inhibited the rise in $\left[\mathrm{Ca}^{2+}\right]_{\text {; }}$ induced by fluprostenol (Fig. 2b insert). Moreover, high extracellular $\mathrm{Ca}^{2+}$ was required for fluprostenol to have a full stimulatory effect (Fig. 2b insert).

\section{Identification of phospholipase $C$ isoforms}

The presence of phospholipase $C$ isoforms in human granulosa cells is demonstrated by Western blotting (Fig. 3a, b). PLC- $\beta 1$ migrated as two immunoreactive bands at 154 and $100 \mathrm{kDa}$. Preabsorbing anti-PLC- $\beta 1$ with its cognate peptide resulted in the loss of both bands (Fig. 3a). This indicates that the $100 \mathrm{kDa}$ band is immunologically related to the main PLC- $\beta 1$. This isoform is known to be highly sensitive to proteolysis, even when cell extracts are freshly prepared in the presence of protease inhibitors (Suh et al., 1988; Park et al., 1993). PLC- $\beta 2$ and PLC- $\beta 3$ isoforms migrated at a molecular mass of approximately 140 and $155 \mathrm{kDa}$, respectively. Both bands were lost when the antibodies were first preincubated with their cognate peptides. The antibody raised against PLC- $\beta 4$ failed to detect this isoform (Fig. 3b).

A strong band of $148 \mathrm{kDa}$ corresponding to PLC- $\gamma \mathrm{I}$ and a smaller band at $90 \mathrm{kDa}$ which is immunologically related to PLC- $\gamma 2$ were also detected (Fig. 3a, b). All the PLC isoforms were found mainly in the cytosolic fraction, although PLC- $\beta 1$ and PLC- $\gamma 1$ appeared to be slightly associated with the membrane fraction.

\section{Involvement of a PLC- $\beta$ pathway}

The presence of PLC- $\beta$ isoforms in myometrial cells is in agreement with their involvement in $G$ protein-mediated
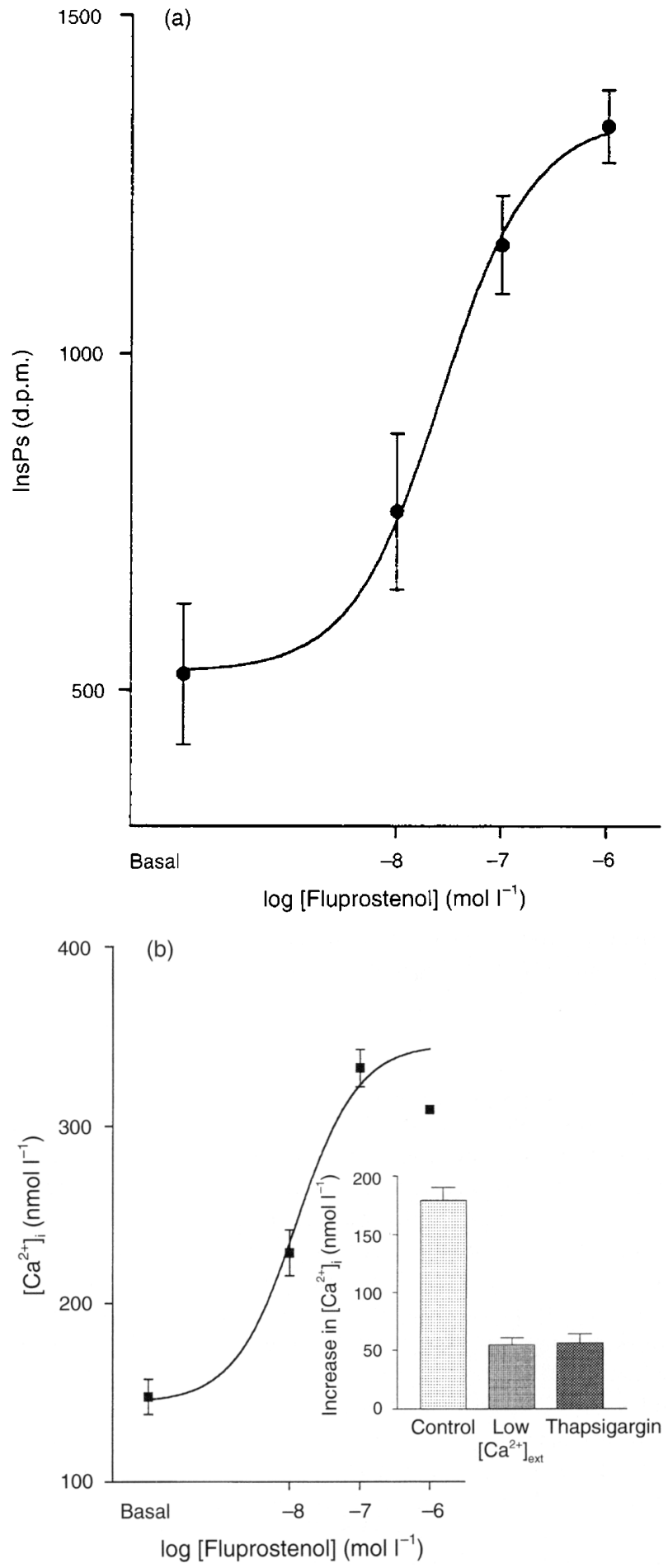

Fig. 2. Concentration-response curve of fluprostenol-stimulated (a) formation of $\left[{ }^{3} \mathrm{H}\right] \mathrm{PS}$ and $(\mathrm{b})\left[\mathrm{Ca}^{2+}\right]_{i}$ mobilization in cultured human granulosa cells. (a) Cells were labelled with $\left[{ }^{3} \mathrm{H}\right]$ myo-inositol and challenged with fluprostenol in the presence of $\mathrm{LiCl}$. (b) Granulosa cells grown on coverslips were loaded with fura-2/acetoxymethyl ester and stimulated with fluprostenol. The inset shows the effect of removing extracellular $\mathrm{Ca}^{2+}$ or depleting intracellular $\mathrm{Ca}^{2+}$ stores with thapsigargin on the $\mathrm{Ca}^{2+}$ peaks provoked by $100 \mathrm{nmol}$ fluprostenol $\mathrm{I}^{-1}$. Each point represents the mean $\pm \mathrm{SD}$ of quadruplicate determinations from a single experiment. Similar results were obtained with cells from a different donor. 


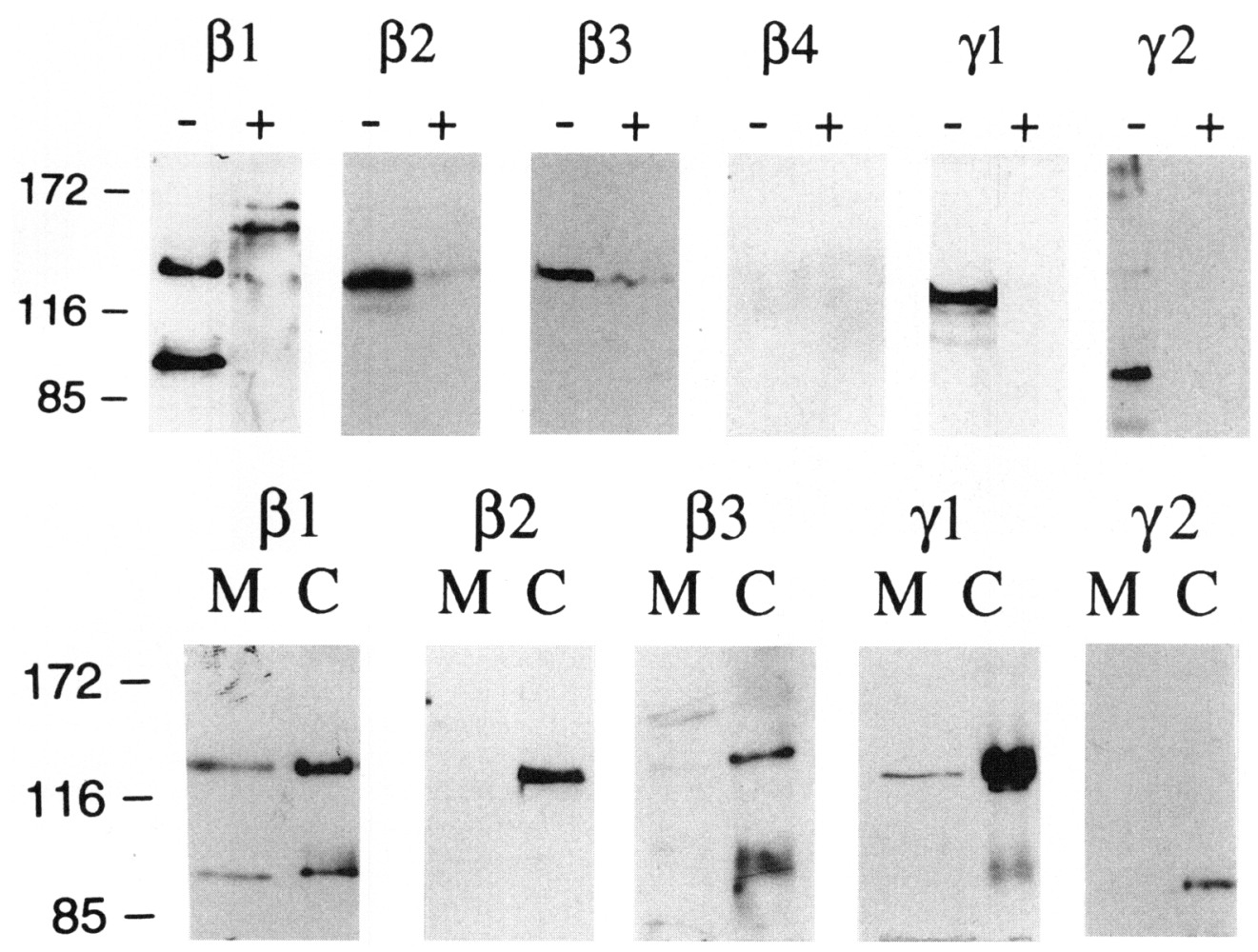

Fig. 3. Identification of phospholipase C (PLC) isoforms in human granulosa cells. Proteins were resolved by polyacrylamide gel electrophoresis and PLC isoforms were revealed by western blotting and enhanced chemiluminescense (ECL) detection. The positions of the molecular mass standards $(\mathrm{kDa})$ are indicated on the left. (a) Antibodies were preincubated with $(+)$ and without $(-)$ their respective cognate peptides before immunodetection. (b) Cellular distribution of PLC isoforms in membrane (M) and cytosolic (C) fractions. Results are from a representative experiment, and similar findings were obtained with cells from another donor.

receptor signalling. By contrast, PLC- $\gamma$ isoforms are regulated by tyrosine kinase activity (Blake et al., 1993). Pervanadate, an inhibitor of tyrosine phosphatases (Gordon, 1991), was used to study PLC- $\gamma$ activation in human granulosa cells and to compare the response to that of fluprostenol. Pervanadate provoked a high level of tyrosine phosphorylation as demonstrated by immunoblotting with anti-phosphotyrosine antibody (Fig. 4). The identity of the phosphorylated proteins was not determined, but they may represent proteins with molecular mass similar to those of PLC- $\gamma$ isoforms (for example 148 and $90 \mathrm{kDa}$ ). Neither fluprostenol nor oxytocin, the receptors of which operate through a G protein PLC pathway (Phaneuf et al., 1993) promoted tyrosine phosphorylation. Pervanadate stimulated IP formation fourfold over control and this effect was significantly inhibited by phenylarsine oxide (PAO), a compound that inhibits tyrosine phosphorylation (Yanaga et al., 1995) (Fig. 5). By contrast, the stimulatory effect of fluprostenol was not affected by PAO (Fig. 5). Furthermore, when cells were treated with PDBu, an activator of PKC, the PLC response to fluprostenol was almost abolished (Fig. 5), whereas the response to pervanadate was less affected. Activation of PKC has an inhibitory feedback effect predominantly on G protein-linked PLC- $\beta$ activity (Biffen et al., 1993; Carrasco et al., 1996). Taken together, these results suggest that the FP receptor in granulosa cells signals through a PLC- $\beta$, rather than PLC- $\gamma$ pathway.

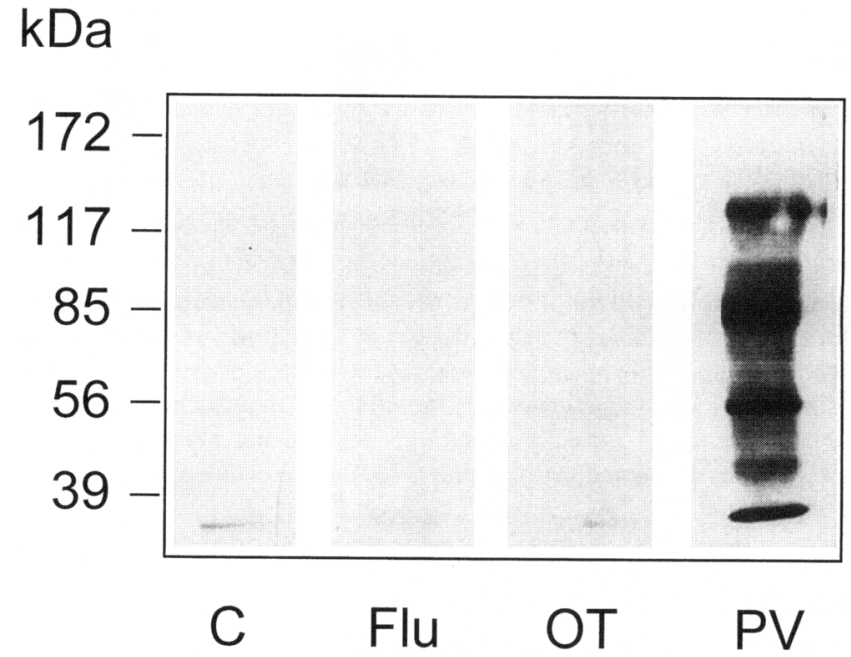

Fig. 4. Detection of tyrosine-phosphorylated proteins in human granulosa cells. Cells were stimulated with fluprostenol (Flu; $1 \mu \mathrm{mol}$ $\mathrm{I}^{-1}$ ), oxytocin (OT; $1 \mu \mathrm{mol} \mathrm{l}^{-1}$ ), or pervanadate (PV; a mixture of $400 \mu \mathrm{mol}$ sodium orthovanadate $\mathrm{I}^{-1}$ and $2 \mathrm{mmol} \mathrm{H}_{2} \mathrm{O}_{2} \mathrm{l}^{-1}$ ). Proteins were resolved by polyacrylamide gel electrophoresis and phosphotyrosine was revealed by western blotting and enhanced chemiluminescense (ECL) detection. The positions of the molecular mass standards $(\mathrm{kDa})$ are indicated on the left. Results are from a representative experiment, and similar findings were obtained with cells from two other donors. 

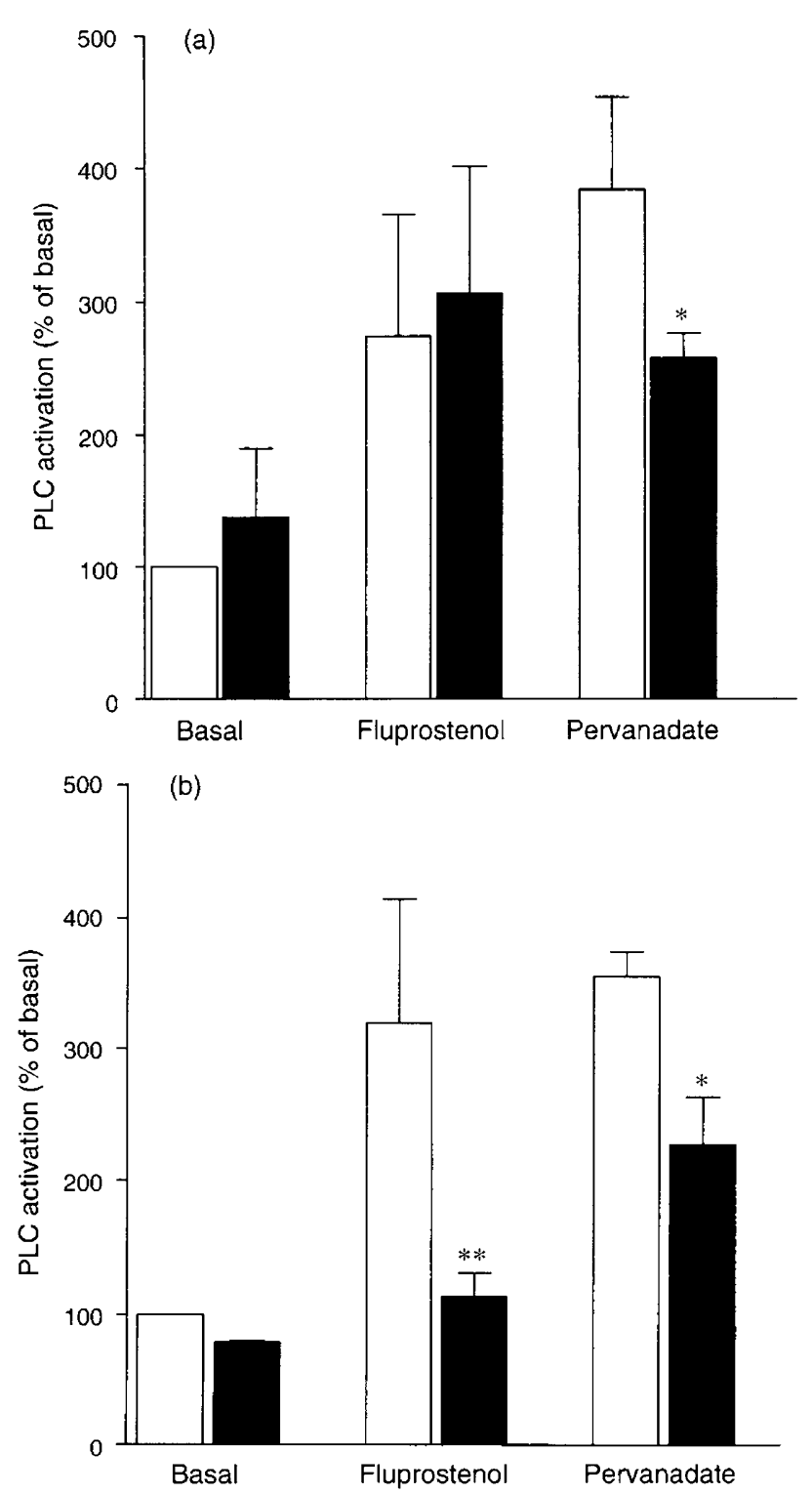

Fig. 5. Effects of (a) phenylarsine oxide (PAO) and (b) phorbol 12,13-dibutyrate ( $\mathrm{PDBu}$ ) on fluprostenol- and pervanadate-stimulated formation of $\left[{ }^{3} \mathrm{H}\right] \mathrm{IPs}$ in cultured human granulosa cells. Cells were labelled with $\left[{ }^{3} \mathrm{H}\right]$ myo-inositol and were challenged with fluprostenol ( $1 \mu \mathrm{mol} \mathrm{^{-1 }}$ ) or pervanadate (a mixture of $400 \mu \mathrm{mol}$ sodium orthovanadate $\mathrm{l}^{-1}$ and $\left.2 \mathrm{mmol} \mathrm{H}_{2} \mathrm{O}_{2} \mathrm{l}^{-1}\right)$ in the presence of $\mathrm{LiCl}$. Cells were stimulated with agonists in the absence (control; $\square$ ) or presence $(\mathbf{a})$ of PAO $\left(1 \mu \mathrm{mol} \mathrm{l^{-1 }}\right)$ or PDBu $\left(1 \mu \mathrm{mol} \mathrm{1^{-1 }}\right)$, which were added 5 and $10 \mathrm{~min}$ before the agonists, respectively. Results are expressed as relative change and are the mean \pm SD of quadruplicate determinations from single representative experiments. The findings were confirmed with cells from different donors. Statistical differences compared with cells without inhibitor: ${ }^{*}, P<0.05$; ${ }^{* *}$, $P<0.01$

\section{Expression of $G a_{q}$ and $G a_{11}$ genes in human granulosa cells}

For identifying the class of $G$ protein involved in the mechanism of FP receptor activation, granulosa cells were pretreated with $0.5 \mu \mathrm{g}$ pertussis toxin $\mathrm{ml}^{-1}$ for $16 \mathrm{~h}$ before being challenged with fluprostenol. The effect of fluprostenol

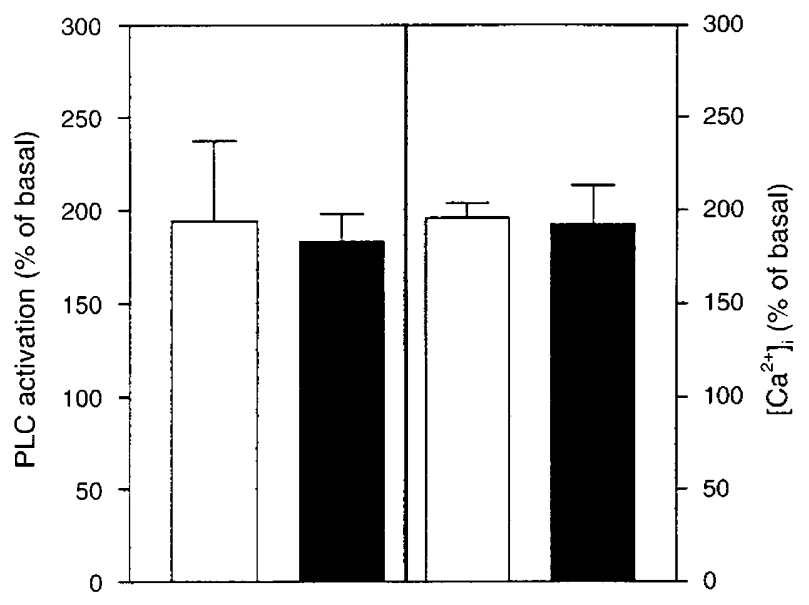

Fig. 6. Effect of pertussis toxin on fluprostenol-stimulated PLC activation and changes in $\left[\mathrm{Ca}^{2+}\right]_{\mathrm{i}}$ in human granulosa cells. Cells were preincubated with ( $\square$ ) and without $(\square) 0.5 \mu \mathrm{g}$ pertussis toxin $\mathrm{ml}^{-1}$ for $16 \mathrm{~h}$ and were challenged with $0.1 \mu \mathrm{mol}$ fluprostenol $\mathrm{l}^{-1}$. All other conditions were as in Fig. 2. Results are expressed as relative change and are the mean $\pm \mathrm{SD}$ of quadruplicate determinations from a single representative experiment. The findings were confirmed with cells from two different donors.

was resistant to pertussis toxin (Fig. 6), indicating that it is mediated by a protein of the $G_{g}$ family. Human granulosa cells have been shown to express $G$ proteins of the $G_{\mathrm{q}}$ family as demonstrated by immunoblotting, although the antibody used could not distinguish between $\mathrm{G} \alpha_{q}$ and $\mathrm{G} \alpha_{11}$ (López Bernal et al., 1995). Here, we have demonstrated the presence of mRNA for both $G \alpha_{q}$ and $G \alpha_{11}$ in granulosa cells. RT-PCR analysis using $\mathrm{Ga}_{q^{-}}$and $\mathrm{Ga}_{11^{-}}$-specific primers that were designed to produce a $508 \mathrm{bp}$ and a $529 \mathrm{bp}$ fragment, respectively, resulted in the amplification of single bands (Fig. 7). The identity of the PCR products was confirmed by sequencing which showed $100 \%$ homology with the published sequences (Jiang et al., 1991; Chen et al., 1996).

\section{Discussion}

The data reported here show that activation of FP receptors in human granulosa cells with the selective agonist fluprostenol results in a dose-dependent stimulation of PLC and an increase in $\left[\mathrm{Ca}^{2+}\right]_{\mathrm{i}}$ concentrations and confirm that $\mathrm{PGF}_{2 i 2}$ may be an important physiological modulator of ovarian activity (McNatty et al., 1975; Thomas et al., 1978; Hamberger et al., 1979; Pate and Condon, 1984; Michael and Webley 1993) through a pathway that involves activation of the inositol phospholipid pathway. $\mathrm{PGF}_{2 \alpha}$ operates through the FP receptor which has recently been cloned from human uterine tissues. This receptor displays the characteristic seven-transmembrane domains of $G$ protein-coupled receptors (Abramovitz et al., 1994). Binding studies with radiolabelled $\mathrm{PGF}_{2 u}$ indicated the presence of FP receptors in human luteal cells (Powell et al., 1974; Auletta et al., 1990; Olofsson and Leung, 1994), and recently, Ristimäki et al. (1997) have cloned a partial cDNA sequence of the FP receptor from human granulosa cells. We have demonstrated the presence of FP receptor mRNA in 
(a)

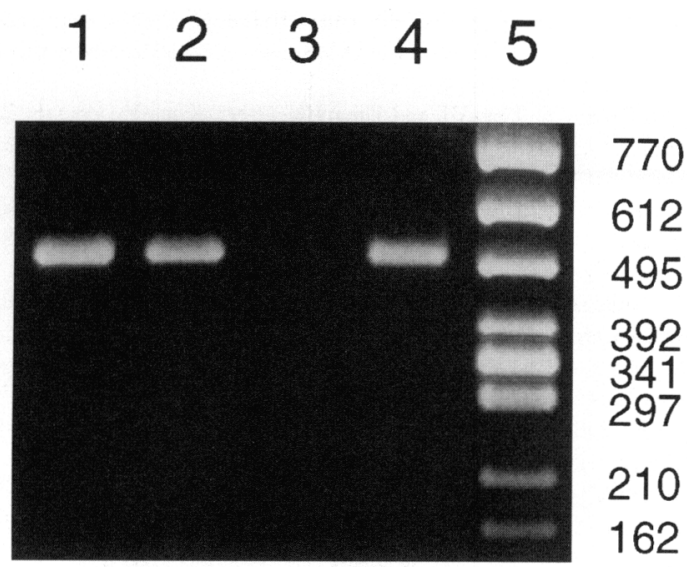

(b)
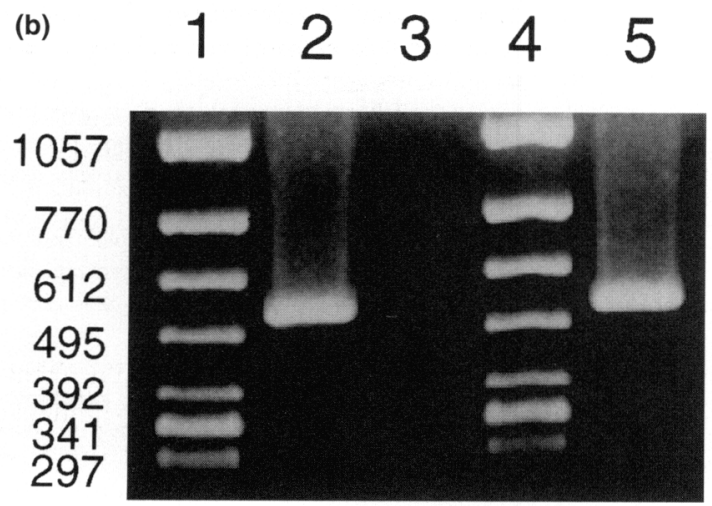

Fig. 7. (a) Expression of $\mathrm{G} \alpha_{q}$ gene in human granulosa cells. RT-PCR analysis of $\mathrm{G} \alpha_{4}$ produced the expected 508 bp band (lanes 1, 2 and 4; three different donors). A PCR sample without RNA transcribed product was loaded in lane 3 (blank). Lane 5 contained the DNA size markers (bp). (b) Expression of $\mathrm{G} \alpha_{11}$ gene in human granulosa cells. RT-PCR analysis of $\mathrm{G} \alpha_{11}$ produced the expected $529 \mathrm{bp}$ band (lane 2). A PCR sample without RNA transcribed product was loaded in lane 3 (blank). Lanes 1 and 4 contain DNA size markers. A sample of human myometrial cells was applied in lane 5 for comparison. The identity of the PCR products was confirmed by sequencing.

granulosa cells by RT-PCR using a different set of primers from those used by Ristimäki et al. (1997). Moreover, Pierce et al. (1997) have cloned two isoforms of the FP receptor from an ovine large luteal cell library, with minor differences in the carboxy terminus.

Furthermore, in the present study we have shown that human granulosa cells express three subtypes of PLC- $\beta$ ( $\beta 1, \beta 2$ and $\beta 3)$ and two subtypes of PLC- $\gamma(\gamma 1$ and $\gamma 2)$ raising the possibility that FP receptors operate through tyrosine kinase as well as G protein-coupled pathways (Watanabe et al, 1994). In addition, we have demonstrated by RT-PCR that mRNAs for two pertussis toxin-resistant $G$ proteins, $G \alpha_{q}$ and $G \alpha_{11}$, are present in abundance in cultured granulosa cells. Since $G$ proteins of the $G_{q}$ family activate PLC- $\beta$ rather than PLC- $\gamma$ isoforms (Rhee and Choi, 1992), it is suggested that in granulosa cells the FP receptor operates by increasing phosphoinositide formation and $\left[\mathrm{Ca}^{2+}\right]_{i}$ through a $\mathrm{G}_{\mathrm{q}} / \mathrm{PLC}-\beta$ pathway.
This is supported by the fact that despite the high expression of PLC- $\gamma$ in cultured human granulosa cells, there was not stimulation of tyrosine phosphorylation in cells treated with the $G$ protein receptor agonists fluprostenol or oxytocin. By contrast, pervanadate produced a marked increase in protein phosphorylation. Moreover, in the PLC activation assays the pattern of response to fluprostenol was very different from the response to pervanadate. Stimulation of PKC by phorbol ester inhibited the response to fluprostenol much more than the response to pervanadate. PLC- $\beta$ isoenzymes are very sensitive to PKC whereas the response to PLC- $\gamma$ enzymes is not affected (Biffen et al., 1993). In addition, PAO, which blocks tyrosine phosphorylation of several proteins (García-Morales et al, 1990; Anel and Kleinfeld, 1993; Yanaga et al, 1995), inhibited the response to pervanadate without having any effect on the response to fluprostenol. These results clearly suggest that fluprostenol operates through a PKC-sensitive pathway such as PLC $\beta$ that is not affected by blocking tyrosine phosphorylation and does not involve PLC- $\gamma$ (Carrasco et al., 1996) This contention is in agreement with the data published by Abayasekara et al. (1993) and Michael et al. (1993) who reported that the actions of $\mathrm{PGF}_{2 u}$ on human and marmoset luteal cells involve a PKC-dependent mechanism.

FP receptors are hormonally regulated. In primates, the activation of PLC by $\mathrm{PGF}_{212}$ is enhanced as the luteal phase progresses (Houmard et al., 1992); however, by day 14 after ovulation the response to $\mathrm{PGF}_{2 \alpha}$ or its analogue cloprostenol is lost, suggesting that in the primate corpus luteum recent exposure to LH or hCG is neccesary to stimulate PLC via FP receptors (Michael and Webley, 1993). In sheep, FP receptor transcripts are high during the mid-luteal phase but decrease during luteolysis (Graves et al., 1995). A similar pattern has been described for bovine FP receptors which are maximally induced $48 \mathrm{~h}$ after the ovulatory LH surge (Sakamoto et al., 1995; Tsai et al., 1996). Interestingly, high levels of FP receptor transcripts are found in bovine corpus luteum during early pregnancy (Sakamoto et al, 1995). Recent experiments in mice, suggest a role for FP receptors in luteal cell apoptosis (Hasumoto et al., 1997) Moreover, Ristimäki et al. (1997) have shown that in human cultured granulosa cells FP receptor mRNA expression is stimulated by hCG through a cyclic AMP-dependent pathway and the effect of hCG was abolished with phorbol ester. Thus, activation of PKC not only inhibits the response of PLC- $\beta$ to the receptor, but also leads to receptor downregulation. Stimulation of FP receptor expression by $\mathrm{LH} / \mathrm{hCG}$ and inhibition by PKC (which can be activated by $\mathrm{PGF}_{2 u}$ itself) may provide a fine balance to regulate the activity and lifespan of the corpus luteum. In conclusion, human granulosa celis express an FP receptor which is functional and activates PLC- $\beta$ probably via a pertussis toxin-resistant $G_{q}$ protein. Our results apply to mature granulosa cells obtained from stimulated IVF cycles after exposure to hCG in vivo and may not apply to granulosa cells at earlier stages of development or to late luteal cells. Further research is necessary to establish the role of FP receptors in the process of luteinization and luteolysis and to define the PLC- $\beta$ subtypes involved. An essential role for FP receptor-induced luteolysis in the initiation of parturition has recently been shown in mice (Sugimoto et al., 1997). 
This work was supported by Wellbeing. The authors are grateful to the staff at the Oxford Fertility Unit and to J. Bellinger for help in the collection and maintenance of granulosa cells.

\section{References}

Abayasekara DR, Michael AE, Webley GE and Flint APF (1993) Mode of action of prostaglandin $\mathrm{F}_{2 a}$ in human luteinized granulosa cells: role of protein kinase C Molecular and Cellular Endocrinology 97 81-91.

Abramovitz M, Boie Y, Nguyen T, Rushmore TH, Bayne MA, Metters KM, Slipetz DM and Grygorczyk R (1994) Cloning and expression of a cDNA for the human prostanoid FP receptor Journal of Biological Chemistry 269 2632-2636 Anel A and Kleinfeld AM (1993) Tyrosine phosphorylation of a 100-kDa protein is correlated with cytotoxic T-lymphocyte function. Evidence from cis unsaturated fatty acid and phenylarsine oxide inhibition journal of Biological Chemistry 26817 578-17587

Asbóth G, Phaneuf S, Europe-Finner GN, Tóth M and López Bernal A (1996) Prostaglandin $\mathrm{E}_{2}$ activates phospholipase $\mathrm{C}$ and elevates intracellular calcium in cultured myometrial cells: involvement of EPI and EP3 receptor subtypes Endocrinology $137 \quad 2572-2579$

Auletta FJ, Schofield MJ and Abae M (1990) The mechanisms controlling luteolysis in non-human primates and women Seminars of Reproductive and Endocrinology 8 122-129

Biffen M, Shiroo M and Alexander DR (1993) G-proteins are not directly involved in the $\mathrm{CD} 3$-antigen-mediated production of inositol phosphates in HPB-ALL T-leukaemia cells expressing phospholipase $C$ isoforms $\gamma 1$ and $\beta 3$ Biochemical journal 289 387-394

Blake RA, Walker TR and Watson SP (1993) Activation of human platelets by peroxovanadate is associated with tyrosine phosphorylation of phospholipase C- $\gamma$ and formation of inositol phosphates Biochemical Joumal 290 471-475

Bone EA, Fretten P, Palmer S, Kirk CJ and Michell RH (1984) Rapid accumulation of inositol phosphates in isolated rat superior cervical sympathetic ganglia exposed to $V_{1}$-vasopressin and muscarinic cholinergic stimuli Biochemical Journal 221 803-811

Carrasco MP, Phaneuf S, Asbóth G and López Bernal A (1996) Fluprostenol activates phospholipase $\mathrm{C}$ and $\mathrm{Ca}^{2+}$ mobilization in human myometrial cells Journal of Clinical Endocrinology and Metabolism 81 2104-2110

Chen BW, Leverette RD, Schwinn DA and Kwatra MM (1996) Human G(alphaQ)-cDNA and tissue distribution Biochimica et Biophysica Acta 1281 125128

Chirgwin JM, Przybyla AE, Macdonald RJ and Rutter WJ (1979) Isolation of biologically active ribonucleic acid from sources enriched in ribonuclease Biochemistry 18 5294-5299

Currie WD, Li W, Baimbridge KG, Yuen BH and Leung PC (1992) Cytosolic free calcium increased by prostaglandin $\mathrm{F}_{2 \mu}\left(\mathrm{PGF}_{2 \alpha}\right)$, gonadotropin-releasing hormone, and angiotensin II in rat granulosa cells and PGF $_{2,4}$ in human granulosa cells Endocrinology 130 1837-1843

Dennefors BL, Sjorgen A and Hamberger L (1982) Progesterone and adenosine $3^{\prime}, 5^{\prime}$-monophosphate formation by isolated human corpora lutea of different ages: influences of human chorionic gonadotrophin and prostaglandins Journal of Clinical Endocrinology and Metabolism 55 102-107

Dukes M, Russell W and Walpole AL (1974) Potent luteolytic agents related to prostaglandin $\mathrm{F}_{2 u}$ Nature 250 330-33I

Garcia-Morales P, Minami Y, Luong E, Klausner RD and Samelson LE (1990) Tyrosine phosphorylation in $\mathrm{T}$ cells is regulated by phosphatase activity: studies with phenylarsine oxide Proceedings of the National Acaderny of Sciences USA 87 9255-9259

Gordon JA (1991) Use of vanadate as protein-phosphotyrosine phosphatase inhibitor Methods in Enzymology 201 477-482

Graves PE, Pierce KL, Bailey TJ Rueda BR, Gil DW, Woodward DF, Yool AJ, Hoyer PB and Regan JW (1995) Cloning of a receptor for prostaglandin $\mathrm{F}_{20}$ from the ovine corpus luteum Endocrinology 136 3430-3436

Grynkiewicz G, Poenie M and Tsien RY (1985) A new generation of $\mathrm{Ca}^{2+}$ indicators with greatly improved fluorescence properties Journal of Biological Chemistry 260 2440-2450

Hamberger L, Nilsson L, Dennefors B, Khan I and Sjorgen A (1979) Cyclic AMP formation of isolated human corpora lutea in response to hCG-interference by $\mathrm{PGF}_{2 \alpha}$ Prostaglandins 17 615-621

Hasumoto K, Sugimoto Y, Yamasaki A, Morimoto K, Kakizuka A, Negishi M and Ichikawa A (1997) Association of expression of mRNA encoding the PGF receptor with luteal cell apoptosis in ovaries of pseudopregnant mice Journal of Reproduction and Fertility 109 45-51
Houmard BS, Guan Z, Stokes BT and Ottobre JS (1992) Activation of the phosphatidylinositol pathway in the primate corpus luteum by prostaglandin $F_{2 u}$ Endocrinology $131743-748$

Jiang M, Pandey S, Tran VT and Fong HK (1991) Guanine nucleotide-binding regulatory proteins in retinal epithelial celis Proceedings of the National Academy of Sciences USA 88 3907-3911

Kitanaka JI, Hasimoto H, Sugimoto Y, Negishi M, Aino H, Gotoh M, Ichikawa A and Baba A (1994) Cloning and expression of a cDNA for rat prostaglandin $\mathrm{F}_{2,}$ receptor Prostaglandins 48 31-4 I

Lake S, Gullberg H, Wahlqvist J, Sjögren AM, Kinhult A, Lind P, Hellström LE and Stjernschantz J (1994) Cloning of the rat and human prostaglandin $F_{2 u}$ receptors and the expression of the rat prostaglandin $\mathrm{F}_{2 a}$ receptor $F E B S$ Letters $355 \quad 317-325$

Liebermann J, Schams D and Miyamoto A (1996) Effects of local growth factors on secretory function of bovine corpus luteum during the oestrous cycle and pregnancy in vitro. Reproduction, Fertility and Development 8 1003-1011

López Bernal A, Bellinger J, Marshall J, Phaneuf S, Europe-Finner GN, Asbóth G and Barlow DH (1995) G-protein expression and second messenger formation in human granulosa cells Journal of Reproduction and Fertility 104 77-83

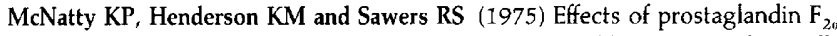
and $E_{2}$ on the production of progesterone by cultured human granulosa cells in tissue culture Journal of Endocrinology 67 231-240

Michael AE and Webley GE (1991) Prior exposure to gonadotrophins prevents the subsequent antigonadotrophic effects of cloprostenol by a cyclic AMP-dependent mechanism in cultured human granulosa cells Journal of Endocrinology 131 319-325

Michael AE and Webley GE (1993) The roles of cyclic AMP and inositol phosphates in the luteolytic action of cloprostenol, a prostaglandin $F_{20}$ analogue, in marmoset monkeys Journal of Reproduction and Fertility 97 425-431

Michael AE, Abayasekara DRE and Webley GE (1993) The luteotrophic actions of prostaglandins $E_{2}$ and $F_{20}$ on dispersed marmoset luteal cells are differentially mediated via cyclic AMP and protein kinase $C$ journal of Endocrinology 138 291-298

Olofsson J and Leung PC (1994) Auto/paracrine role of prostaglandins in corpus luteum function Molecular and Cellular Endocrinology 100 87-91

Park DG, Jhon DY, Lee CW, Ryu SH and Rhee SG (1993) Removal of the carboxyl-terminal region of phospholipase $\mathrm{C}-\beta 1$ by calpain abolishes activation by $\mathrm{G} \alpha_{4}$ Journal of Biological Chemistry 268 3710-3714

Pate JL and Condon WA (1984) Effects of prostaglandin F2 alpha on agonistinduced progesterone production in cultured bovine luteal cells Biology of Reproduction 31 427-435

Phaneuf S, Europe-Finner GN, Varney M, MacKenzie IZ, Watson SP and López Bernal A (1993) Oxytocin-stimulated phosphoinositide hydrolysis in human myometrial cells: involvement of pertussis toxin-sensitive and -insensitive G-proteins Journal of Endocrinology 136 497-509

Phaneuf S, Carrasco MP, Europe-Finner GN, Hamilton CH and López Bernal A (1996) Multiple $G$ proteins and phospholipase $C$ isoforms in human myometrial cells: implication for oxytocin action 81 2098-2103

Pierce KL, Bailey TJ, Hoyer PB, Gil DW, Woodward DF and Regan JW (1997) Cloning of a carboxyl-terminal isoform of the prostanoid FP receptor Journal of Biological Chemistry 272 883-887

Powell WS, Hammarstrom S, Samuelsson B and Sjoberg B (1974) Prostaglandin F2 alpha receptor in human corpora lutea Lancet i 866-1120

Prins BA, Hu RM, Nazario B, Pedram A, Frank HJ, Weber MA and Levin ER (1994) Prostaglandin E2 and prostacyclin inhibit the production and secretion of endothelin from cultured endothelial cells Journal of Biological Chemistry $26911938-11944$

Rhee SG and Choi KD (1992) Multiple forms of phospholipase C isoenzymes and their activation mechanisms Advances in Second Messenger Phosphoprotein Research 26 35-61

Ristimäki A, Jaatinen R and Ritvos $O$ (1997) Regulation of prostaglandin $F_{2 u}$ receptor expression in cultured human granulosa-luteal cells Endocrinology 138 191-195

Sakamoto K, Ezashi T, Miwa K, Okuda-Ashitaka E, Houtani T, Sugimoto T, Ito S and Mayaishi O (1994) Molecular cloning and expression of a CDNA of the bovine prostaglandin $F_{2 u}$ receptor Journal of Biological Chemistry 269 $3881-3886$

Sakamoto K, Miwa K, Ezashi T, Okuda-Ashitaka E, Okuda K, Houtani T, Sugimoto $T$, Ito $S$ and Hayaishi $O$ (1995) Expression of mRNA encoding the prostaglandin $\mathrm{F}_{2 u}$ receptor in bovine corpora lutea throughout the oestrous cycle and pregnancy Journal of Reproduction and Fertility 103 99-105 
Sugimoto Y, Hasumoto K, Namba T, Irie A, Katsuyama M, Negishi M, Kakizuka A, Narumiya S and Ichikawa A (1994) Cloning and expression of a cDNA for mouse prostaglandin F receptor Journal of Biological Chemistry 269 13561360

Sugimoto $Y$, Yamasaki A, Segi E, Tsuboi K, Aze Y, Nishimura T, Oida H, Yoshida N, Tanaka T, Katsuyama M, Hasumoto K, Murata T, Hirata M, Ushikubi F, Negishi M, Ichikawa A, and Narumiya S (1997) Failure of parturition in mice lacking the prostaglandin F receptor Science 277 681-683

Suh PG, Ryu SH, Choi WC, Lee KY and Rhee SG (1988) Monoclonal antibodies to 3 phospholipase $C$ isoenzymes from bovine brain Journal of Biological Chemistry 26314 497-14 504

Thastrup O, Cullen PJ, Drobak BK, Hanley MR and Dawson AP (1990) Thapsigargin, a tumor promoter, discharges intracellular $\mathrm{Ca}^{2+}$ stores by specific inhibition of the endoplasmic reticulum $\mathrm{Ca}^{2+}$-ATPase Proceedings of the National Academy of Sciences USA 87 2466-2470
Thomas JP, Dorflinger LJ and Behrman HR (1978) Mechanism of the rapid antigonadotropic action of prostaglandins in cultured luteal cells Proceedings of the National Academy of Sciences USA 75 1344-1348

Tsai SJ, Wiltbank MC and Bodensteiner KJ (1996) Distinct mechanisms regulate induction of messenger ribonucleic acid for prostaglandin $\mathrm{G} / \mathrm{H}$ synthase-2, PGE $\left(\mathrm{EP}_{3}\right)$ receptor, and $\mathrm{PGF}_{2 a}$ receptor in bovine preovulatory follicles Endocrinology 137 3348-3355

Watanabe T, Nakao A, Emmerling D, Hashimoto $Y$, Tsukamoto $K$, Horie $Y$, Kinoshita $\mathbf{M}$ and Kurokawa $\mathrm{K}$ (1994) Prostaglandin $\mathrm{F}_{2 \mathrm{u}}$ enhances tyrosine phosphorylation and DNA synthesis through phospholipase C-coupled receptor via $\mathrm{Ca}^{2+}$-dependent intracellular pathway in NIH-3T3 cells Journal of Biological Chemistry 26917 619-17 625

Yanaga F, Asselin J, Schieven GL and Watson SP (1995) Phenylarsine oxide inhibits tyrosine phosphorylation of phospholipase $\mathrm{C}-\gamma 2$ in human platelets and phospholipase C- $\gamma 1$ in NIH-3T3 fibroblasts FEBS Letters 368 377-380 